\title{
Assessment of Groundwater Quality of Ilorin Metropolis using Water Quality Index Approach
}

\author{
J. A. Olatunji ${ }^{1 *}$, O. A. Odediran ${ }^{1}$, R. I. Obaro ${ }^{1}$, P. I. Olasehinde ${ }^{2}$ \\ ${ }^{1}$ Department of Minerals \& Petroleum Resources Engineering Technology, Kwara State Polytechnic, Ilorin, Nigeria. \\ ${ }^{2}$ Department of Geology, Federal University of Technology, Minna, Nigeria.
}

\begin{abstract}
Groundwater as a source of potable water is becoming more important in Nigeria. Therefore, the need to ascertain the continuing potability of the sources cannot be over emphasised. This study is aimed at assessing the quality of selected groundwater samples from Ilorin metropolis, Nigeria, using the water quality index (WQI) method. Twenty two water samples were collected, 10 samples from boreholes and 12 samples from hand dug wells. All these were analysed for their physico chemical properties. The parameters used for calculating the water quality index include the following: $\mathrm{pH}$, total hardness, total dissolved solid, calcium, fluoride, iron, potassium, sulphate, nitrate and carbonate. The water quality index for the twenty two samples ranged from 0.66 to 756.02 with an average of 80.77. Two of the samples exceeded 100, which is the upper limit for safe drinking water. The high values of WQI from the sampling locations are observed to be due to higher values of iron and fluoride. This study reveals that the investigated groundwaters are mostly potable and can be consumed without treatment. Nonetheless, the sources identified to be unsafe should be treated before consumption.
\end{abstract}

KEYWORDS: groundwater, water quality index, potability, physico - chemical, parameter

[Received October 20 2014; Revised February 252015 \& June 1 2015; Accepted June 6 2015]

\section{INTRODUCTION}

Groundwater plays a vital role as an important source of potable water in both rural and urban areas of Nigeria. It remains the largest available source of fresh water, thus it forms a very important part of the water supply chain. There is a growing demand for groundwater in virtually all parts of Nigeria (Adeyemi et al.). This is due to rapid growth in population and increasing industrial activities. Naturally, surface water is highly susceptible to contamination, but groundwater is less susceptible. However, once groundwater is polluted, remediation is usually very difficult and expensive to undertake. Also, its quality cannot be restored by stopping the pollutants from the source (Purandara and Varadajan, 2003).

Generally, water pollution not only affects water quality but threatens human health, economic development and social prosperity (Milovanovic, 2007). Groundwater quality depends on the quality of recharge water, atmospheric precipitation, in-land surface water, and on sub-surface geochemical processes. The physical and chemical parameters useful for water quality assessment are determined by the presence of both organic and inorganic compounds that are either suspended or dissolved in it. While some of the compounds are toxic to the ecosystem, some constitutes nutrients to aquatic organisms and others are responsible for aesthetics of the water body (Eletta and Adekola, 2005).

Nonetheless, groundwater remains the preferred source of water because of its high quality with respect to potability and the minimum treatment requirement in most cases (Okoro, 2012). Consequently, the need for protection and continuous monitoring of groundwater quality cannot be overemphasized.

*Corresponding author’s e-mail address: olatwise@yahoo.com
Ilorin, the Kwara State capital, shown in Figure 1, like several other emerging cities in Nigeria, is faced with the problem of inadequacy of potable water supply from the public water works. This is invariably owing to the inability of the water supply capacity and infrastructure to keep pace with population growth and industrial demand. Consequently, an increasing number of households and industries are constrained to make alternative and private arrangements to meet their water supply needs.

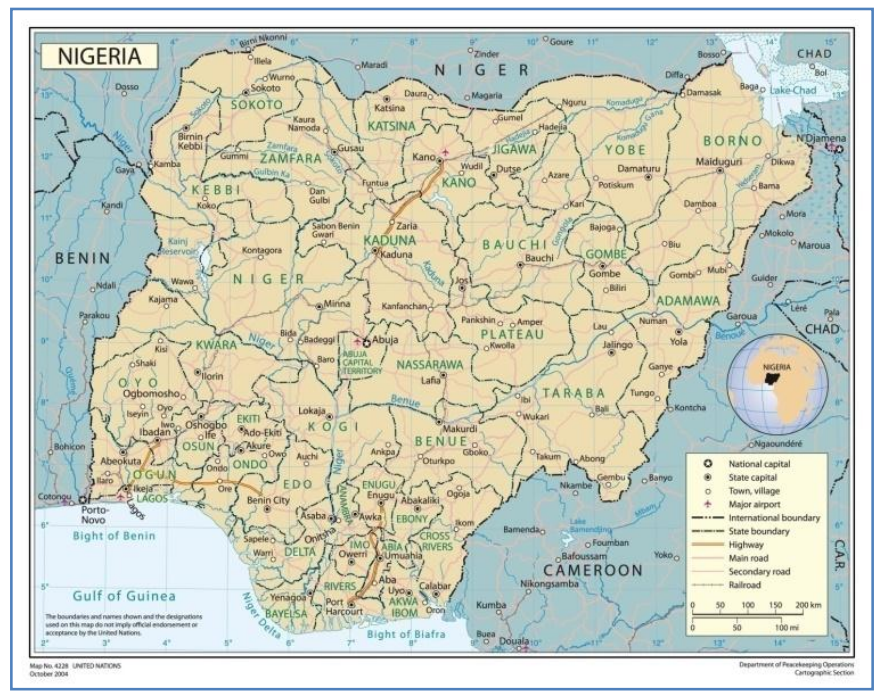

Figure 1: Map of Nigeria showing the location of the study area (modified from United Nations map No. 4228, 2004).

This study is aimed at determining the potability of selected groundwater sources within Ilorin metropolis. The sources include both boreholes and hand-dug wells. In order to achieve the above stated aim, certain chemical and physical 
parameters of the selected water sources were determined and the water quality data were interpreted and presented by the means of water quality index. The concept of water quality index to represent gradation in water quality was first proposed by Horten (1965). This is a simplistic and arguably the most effective way to communicate water quality information devoid of technical complexities. It is essentially defined as a rating reflecting the composite influence of a number of parameters on the overall quality of water (Bangalore and Latha, 2008). It also characteristically indicates a single number like a grade that expresses the overall water quality at a certain place and time based on selected important parameters (Rao and Nageswararao, 2013).

The water quality index approach essentially seeks to turn complex water quality data into information understandable and useable by the public. Although, the concept of water quality index is not yet widely used in Nigeria, Egereonu and Ozuzu (2005) has used it to assess the level of pollution of River Niger while Ubuoh et al. also applied it to determine the susceptibility of water resources to atmospheric pollutant due to petroleum exploitation.

\section{MATERIALS AND METHODS}

A total of 22 water samples were collected using a precleaned 2 liter plastic polyethylene bottles. The sample locations, shown in Figure 2, include both boreholes and hand dug wells. Sampling, preservation and transportation of water samples were done according to standard prescribed by the American Public Health Association (APHA, 2002). Samples were collected during the rainy season, precisely in the month of August. These samples were taken to the laboratory for relevant physico-chemical analyses. The longitude, latitude and elevation of all the sampling locations were also recorded using a Global Positioning System (GPS). The static water level, total depth and water column of each hand dug well were equally measured using meter tape. The water samples were in turn analysed for twenty-five major parameters.

However, only ten parameters were considered in determining the Water Quality Index of the investigated water sources. The considered parameters include: $\mathrm{pH}$, total dissolved solid (TDS), total hardness (TH), Nitrate $\left(\mathrm{NO}_{3}{ }^{-}\right)$, Fluoride $\left(\mathrm{F}^{-}\right)$, Iron $\left(\mathrm{Fe}^{3+}\right)$ and Sulphate $\left(\mathrm{SO}_{4}{ }^{2-}\right)$. They were premised on both the Nigerian standards (NIS, 2007) and the World Health Organisation Standards (WHO, 2006) as appropriate. A calibrated $\mathrm{pH}$ meter and a palintest conductivity meter were used to determine the $\mathrm{pH}$ and the electrical conductivity respectively. The electrical conductivity was subsequently used to estimate the TDS. The other parameters were determined in the laboratory by the use of spectrophotometer and titrimetric methods.

\section{DETERMINATION OF WATER QUALITY INDEX (WQI)}

In determining water quality index, the significance of the different water quality parameters depends on the intended use. This paper seeks to evaluate water quality

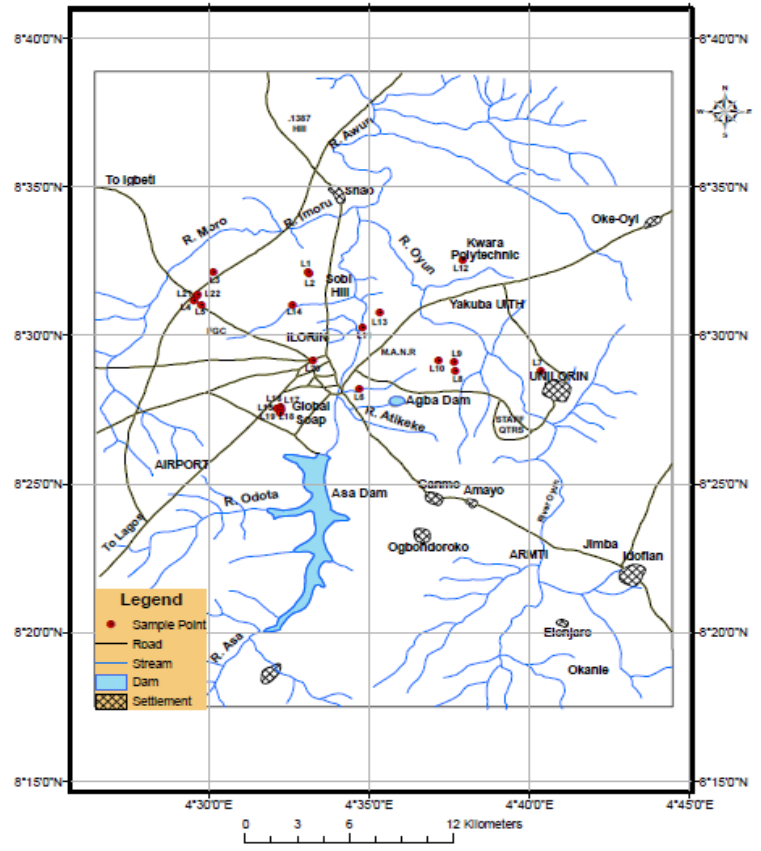

Figure 2: Map showing the sample locations (modified after Olasehinde et al., 1998).

criteria based on the demands for potability. The ten parameters selected for this study are shown in the first column of table 1 . The second column presents the drinking water standards for the parameters $\left(s_{i}\right)$, while the third column gives the unit weights $\left(w_{i}\right)$. The $\mathrm{pH}$ has been assigned the weight of total dissolved solid because they are both secondary pollutants. The water quality index (WQI) can be calculated.

Table 1: Water quality parameters with their WHO/Nigerian standards and unit weights.

\begin{tabular}{lll}
\hline Parameter $\left(\mathbf{P}_{\mathbf{i}}\right)$ & Standard $\left(\mathbf{S}_{\mathbf{i}}\right)$ & Unit weight $\left(\mathbf{W}_{\mathbf{i}}\right)$ \\
\hline $\mathbf{p H}$ & $6.5-8.5$ & 0.001 \\
Total dissolved solid & 1000 & 0.001 \\
Calcium & 200 & 0.005 \\
Fluoride & 1.5 & 0.667 \\
Iron & 0.3 & 3.33 \\
Nitrate & 50 & 0.02 \\
Potassium & 100 & 0.01 \\
Sulphate & 400 & 0.0025 \\
Carbonate & 250 & 0.004 \\
& & \\
Total hardness & 500 & 0.002 \\
\hline
\end{tabular}

Unit weight of the ith parameter $\left(W_{i}\right)$ can be calculated as follows:

$$
w_{i}=K / S_{i}
$$

$\mathrm{K}$ is a constant of proportionality which is assumed to be unity for simplicity.

$$
q_{i}=100\left(V_{i} / S_{i}\right)
$$

Equation (2) defines the quality rating for all the parameters except the $\mathrm{pH}$ whose quality rating is defined by eqons (3) 
and (4) respectively.

$$
\begin{aligned}
& q_{p H}=100\left(V_{p H}-7.0\right) / 1.5 \\
& q_{p H}=100\left(7.0-V_{p H}\right) / 0.5
\end{aligned}
$$

Equation (3) defines the quality rating for $\mathrm{pH}$ values more than the ideal value (7.0), while eqn (4) defines the quality ratings for values less than the ideal value. Finally, the water quality index (WQI) can be calculated by finding the weighted arithmetic mean of the quality rating $\left(\mathrm{q}_{\mathrm{i}}\right)$.

$$
W Q I=\left[\sum\left(q_{i} W_{i}\right) / \sum W_{i}\right]
$$

where $i$ is from 1 to 10 for both summations.

All the notations and equations above with the exception of eqn (4) are adapted from (Bangalor and Latha 2008). Equation (4) is a modification to take care of $\mathrm{pH}$ values less than 7 which were not accounted for by the authors.

\section{RESUlts AND DisCUSSION}

Table 2 shows the results of laboratory analysis of the various water samples from different well locations. This water quality investigation was carried out in the month of August during the rainy season. The results as presented in the table indicate that six out of the tested parameters, fluoride $(\mathrm{F})$, iron $(\mathrm{Fe})$, total hardness $(\mathrm{TH}), \mathrm{pH}$, calcium $\left(\mathrm{Ca}^{2+}\right)$ and nitrate (NO3) occurred in quantities higher than WHO's recommended limits at some sampling locations. Fluoride (F) exceeded the WHO limit in nine sampling stations, total hardness (TH) in seven, calcium $\left(\mathrm{Ca}^{2+}\right)$ in three, iron $(\mathrm{Fe})$ in two, $\mathrm{pH}$ also in two stations while nitrate exceeded the limit in one station. Groundwater can be contaminated through various sources. A prevalent form of contamination especially, in residential areas is the faecal contamination. This is usually indicated by a high nitrate concentration. However, only one sampling location contaminated by sources other than faecal contamination and other anthropogenic sources.
The other parameters that exceed the recommended limits could have resulted from the influence of the geology of the study area. The city of Ilorin is underlain by rocks of the Nigerian basement complex, a group of igneous and metamorphic rocks of mainly Precambrian age. These rocks are largely undifferentiated and cover about $50 \%$ of the bedrock geology of Nigeria (Rahaman, 1988). Calcium $\left(\mathrm{Ca}^{2+}\right)$ was possibly leached from the plagioclase feldspars, amphiboles and pyroxene, which are essential constituents of the underlying rocks. In the same vain, fluoride (F) may also be traced to the occurrence of hornblende and biotite in the underlying rocks. The total hardness as well as $\mathrm{pH}$ may be attributed to the action of acidified rain water on both the overburden soil and the bedrock. The results of this investigation suggest that water quality of the sampled locations is defined by the anomalous concentrations of causative minerals in the bedrock of the study area.

On the other hand, sample calculation of WQI for the first sampling location is shown in detail in Table 3. In Table 4, 10 water quality parameters are listed in the first column, while their actual values are given in the second column. The third column in the table shows the quality ratings $q$ for these parameters, while the last column gives the sub-indices). The

Table 3: Water quality index of groundwater samples from Ilorin metropolis.

\begin{tabular}{clll}
\hline $\begin{array}{l}\text { Sample } \\
\text { Location }\end{array}$ & WQI & $\begin{array}{l}\text { Sample } \\
\text { Location }\end{array}$ & WQI \\
\hline 1 & 36.92 & 12 & 17.56 \\
2 & 8.08 & 13 & 25.51 \\
3 & 10.71 & 14 & 0.66 \\
4 & 28.42 & 15 & 69.30 \\
5 & 75.98 & 16 & 68.60 \\
6 & 28.53 & 17 & 12.52 \\
7 & 31.74 & 18 & 30.40 \\
8 & 60.26 & 19 & 304.98 \\
9 & 28.16 & 20 & 756.02 \\
10 & 60.48 & 21 & 13.23 \\
11 & 60.81 & 22 & 12.11 \\
\hline
\end{tabular}

\begin{tabular}{|c|c|c|c|c|c|c|c|c|c|c|c|}
\hline $\begin{array}{c}\text { Sample } \\
\text { Location }\end{array}$ & $\mathbf{p H}$ & $\begin{array}{c}\text { TDS } \\
\mathrm{mg} / \mathrm{L} \\
\end{array}$ & $\begin{array}{c}\mathrm{Ca} \\
\mathrm{mg} / \mathrm{L}\end{array}$ & $\begin{array}{c}\text { F } \\
\mathrm{mg} / \mathrm{L}\end{array}$ & $\begin{array}{c}\mathrm{Fe} \\
\mathrm{mg} / \mathrm{L}\end{array}$ & $\begin{array}{c}\mathrm{NO}_{3} \\
\mathrm{mg} / \mathrm{L} \\
\end{array}$ & $\begin{array}{c}\mathrm{K} \\
\mathrm{mg} / \mathrm{L}\end{array}$ & $\begin{array}{c}\mathrm{SO}_{4} \\
\mathrm{mg} / \mathrm{L}\end{array}$ & $\begin{array}{r}\mathrm{CO}_{3} \\
\mathrm{mg} / \mathrm{L} \\
\end{array}$ & $\begin{array}{c}\text { TH } \\
\mathrm{mg} / \mathrm{L}\end{array}$ & $\begin{array}{c}\text { Type } \\
\text { of well }\end{array}$ \\
\hline 1 & 8.0 & 167.00 & 25.60 & 1.60 & 0.07 & 10.40 & 8.30 & 0 & 18.00 & 108.00 & $\mathrm{BH}$ \\
\hline 2 & 7.5 & 234.00 & 210 & 0.71 & 0 & 23.10 & 15.20 & 20.00 & 10.00 & 750.00 & HDW \\
\hline 3 & 7.7 & 183.00 & 184.80 & 0.93 & 0 & 26.90 & 2.10 & 0 & 19.00 & 660.00 & HDW \\
\hline 4 & 7.2 & 28.60 & 16.80 & 1.56 & 0.04 & 30.00 & 4.10 & 0 & 0.50 & 60.00 & $\mathrm{BH}$ \\
\hline 5 & 8.6 & 250.30 & 176.80 & 0.61 & 0.25 & 44.00 & 10.70 & 15.00 & 32.00 & 680.00 & HDW \\
\hline 6 & 8.6 & 69.85 & 133.80 & 0.81 & 0.07 & 21.10 & 6.30 & 0 & 122.00 & 478.00 & $\mathrm{BH}$ \\
\hline 7 & 8.5 & 70.20 & 53.70 & 1.10 & 0.07 & 33.00 & 12.00 & 0 & 36.00 & 192.00 & $\mathrm{BH}$ \\
\hline 8 & 7.4 & 130.00 & 104.20 & 1.70 & 0.15 & 31.00 & 0 & 0 & 41.00 & 372.00 & HDW \\
\hline 9 & 7.6 & 83.20 & 82.70 & 0.53 & 0.08 & 27.30 & 6.50 & 0 & 15.00 & 318.00 & HDW \\
\hline 10 & 7.5 & 59.80 & 50.90 & 1.72 & 0.15 & 35.00 & 7.80 & 0 & 12.00 & 196.00 & $\mathrm{BH}$ \\
\hline 11 & 7.4 & 85.80 & 78.50 & 2.50 & 0.12 & 32.00 & 4.20 & 0 & 32.00 & 302.00 & $\mathrm{BH}$ \\
\hline 12 & 7.2 & 56.50 & 46.30 & 1.56 & 0 & 37.00 & 3.40 & 0 & 17.00 & 178.00 & HDW \\
\hline 3 & 7.3 & 301.60 & 276.60 & 1.51 & 0.03 & 39.00 & 0 & 0 & 46.00 & 1064.00 & $\mathrm{BH}$ \\
\hline 14 & 8.5 & 373.10 & 261.60 & 0 & 0 & 31.00 & 6.10 & 0.41 & 105.00 & 1006.00 & HDW \\
\hline 15 & 7.2 & 144.30 & 98.80 & 1.76 & 0.18 & 32.00 & 18.40 & 1.95 & 38.00 & 380.00 & HDW \\
\hline 16 & 7.2 & 74.10 & 73.30 & 0.95 & 0.21 & 45.00 & 7.10 & 0.06 & 24.00 & 282.00 & HDW \\
\hline 17 & 7.5 & 176.80 & 88.40 & 1.11 & 0 & 16.80 & 19.60 & 45.00 & 19.00 & 340.00 & HDW \\
\hline 18 & 7.1 & 81.90 & 114.20 & 1.69 & 0.04 & 34.00 & 15.30 & 0 & 36.00 & 440.00 & HDW \\
\hline 19 & 7.3 & 216.40 & 153.40 & 1.00 & 1.20 & 49.00 & 20.00 & 0 & 109.00 & 590.00 & HDW \\
\hline 20 & 7.4 & 384.80 & 239.20 & 0.55 & 2.73 & 56.00 & 17.50 & 30.00 & 96.00 & 920.00 & $\mathrm{BH}$ \\
\hline 21 & 7.5 & 72.80 & 34.80 & 0.42 & 0.03 & 31.00 & 8.30 & 5.00 & 36.00 & 134.00 & $\mathrm{BH}$ \\
\hline 22 & 7.7 & 83.80 & 65 & 0.81 & 0.01 & 34.00 & 4.70 & 0 & 118.00 & 250.00 & $\mathrm{BH}$ \\
\hline
\end{tabular}

Average value of $\mathrm{WQI}=80.77$.

Table 2: Results of physico - chemical analysis of groundwater samples. 
water quality index as calculated for the first sampling location is found to be 36.92. Likewise, the water quality indices for the other 21 locations sampled were calculated using the groundwater quality data.

Table 4: Sample calculation of water quality Index for sample location 1.

\begin{tabular}{lccc}
\multicolumn{1}{c}{ location 1. } & Observed \\
Palue $\left(\mathbf{V}_{\mathbf{i}}\right)$ & $\begin{array}{c}\text { Quality } \\
\left(\mathbf{q}_{\mathbf{i}}\right)\end{array}$ & $\begin{array}{c}\text { Sub index } \\
\left(\mathbf{q}_{\mathbf{i}} \mathbf{W}_{\mathbf{i}}\right)\end{array}$ \\
\hline $\mathrm{pH}$ & 8.0 & 66.7 & 0.067 \\
$\mathrm{TDS}$ & 167.0 & 16.7 & 0.017 \\
Calcium $(\mathrm{Ca})$ & 25.60 & 12.8 & 0.064 \\
Fluoride $(\mathrm{F})$ & 1.60 & 106.7 & 71.169 \\
Iron $(\mathrm{Fe})$ & 0.07 & 23.3 & 77.589 \\
Nitrate $\left(\mathrm{NO}_{3}\right)$ & 10.50 & 21 & 0.42 \\
Potassium $\left(\mathrm{K}_{\mathbf{i}}\right)$ & 8.30 & 8.3 & 0.083 \\
Sulphate $\left(\mathrm{SO}_{4}\right)$ & 0 & 0 & 0 \\
Carbonate $\left(\mathrm{CO}_{3}\right)$ & 18.0 & 7.2 & 0.029 \\
Total hardness $(\mathrm{TH})$ & 8.30 & 21.6 & 0.0432 \\
\hline
\end{tabular}

Figure 3 shows the percentage of wells that are potable to be $91 \%$ compared to $9 \%$ that did not satisfy the WQI criteria. The numerical value of the WQI, as shown in the previous sections, eqns (2) and (3), implies that the water under consideration is fit for consumption if its WQI $<100$, and is unfit for drinking without treatment if its WQI $\geq 100$. Moreover, the larger the value of WQI, the more polluted the water concerned.

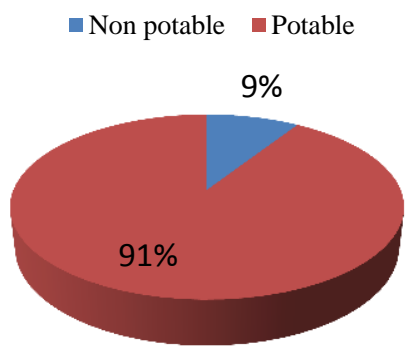

Figure 3: Potability of samples based on water quality index approach.

\section{CONCLUSION}

The accurate interpretation of water quality data is of utmost importance in water quality investigation. Thus, the WQI criteria approach to interpretation is desirable, essentially due to its simplicity. This study essentially suggests that the impairments observed in the groundwaters of the study area are mostly of natural sources. However, regardless of the natural geology and human activities, it has been found that WQI of twenty out of the twenty - two water sources tested, fall within the acceptable limit of less than one hundred $(<100)$ for domestic use and human consumption, while two (Sampling locations 19 and 20) exceeded the limit. Also, the individual values of WQI ranged from a minimum value of 0.66 to a maximum of 756.02 .

The WQI exceeds 100 (safe limit for drinking water) at only two of the 22 sampling locations (19 and 20). Consequently, water from these two sampling locations that is $9 \%$ of sampling locations can be deemed unfit for domestic use and potable purposes without appropriate treatment at the time of this investigation. The high WQI at these locations have been found to be as a result of higher values of fluoride and iron.

\section{REFERENCES}

Adeyemi, G. O., Adesile, A. O. and Obayomi, O. B. (2003). Chemical Characteristics of Some Well waters in Ikire, Southwestern Nigeria. Water Resources, NAH, 14: 1218.

APHA (2002). Standard Methods for the Examination of Water and Waste water, 20th ed. Washington, D.C.: American Public and Health Association.

Bangalore, S. S. and Latha, S. (2008). Assessment of Water Quality Index for the Groundwaters of an Industrial Area in Bangalore, India. Environmental Engineering Science, 25(6): 911- 915.

Egereonu, U. U. and Ozuzu, C. I. U. (2005). "Physicochemical Analysis of the River Niger at Onishia Bank”, Nigeria. J. Chem. Soc. Nigeria, 30: 197-203.

Eletta, O. A. A. (2012). Water Quality Monitoring and Assessment in a Developing Country, Water Quality Monitoring and Assessment, Dr. Voudouris (Ed.), inTech, Available at: http://www.intechopen.com/books/waterquality- monitoring-and-assessment/water-qualitymonitoring-andassessment-in-a-developing-country.

Horten, R. K. (1965). An Index Number for Rating Water Quality. J. Water Pollution Control Federation, 37(3): 300-305.

Milovanovic, M. (2007). Water quality assessment and determination of pollution sources along the Axios/Vardar River, South-eastern Europe. Desalination, 213: 159-173.

NIS (2007). Nigerian Standard for Drinking Water Quality. Nigerian Industrial Standard, Standard Organisation of Nigeria, Abuja.16-17.

Okoro, H. K., Adeyinka, A., Jondiko. O. E., and Ximba, B. J. (2012). Physico-chemical analysis of selected groundwater samples of Ilorin town in Kwara State, Nigeria. Scientific Research and Essays, 7(23): 2063-2069.

Purandara, B. K. And Varandarajan, N. (2003). Impacts on groundwater quality by urbanisation. journal of indian water resources society, 27: 107-115.

Rahaman, M. A., (1988). Recent advances in the study of the Basement Complex of Nigeria. In: Oluyide, P.O., Mbonu, W.C., Ogezi, A.E., Egbuniwe, I.G., Ajibade, A.C. and Umeji A.C. (eds.). Precambrian Geology of Nigeria, G.S.N, 11-41.

Rao, G. S. and Nageswararao, G. (2013). Assessment of groundwater quality using water quality index. Arch. Environ. Sci., 7: 1-5.

Ubuoh, E. A., Akhionbare, S. M. O. Ogbuji, and Akhionbare W.N. (2013). Effectiveness of Water Quality Index in Assessing Water Resources Characteristics in Izombe Oguta Local Government Area of Imo State, Nigeria. International journal of Advanced Biological Research, 3(1): 31-35.

United Nations (2004). Map No. 4228 Department of peace keeping operations cartographic Section.

WHO Guidelines for drinking-water quality (2006). Guidelines for Drinking Water Quality, First Addendum to 3rd ed. Recommendations, World Health Organization, Geneva.1:185-186. 